УДК 343.3

DOI https://doi.org/10.32849/2663-5313/2020.4.48

\title{
Андрій Габуда,
}

канд. юрид. наук, дочент,

дочент кафедри кримінально-правових дисциплін

та оперативно-розшукової діяльності

Прикарпатського факультету

Національної академї внутрішніх справ

\section{Сергій Репецький,}

канд. юрид. наук,

завідувач кафедри кримінального права і прочесу

юридичного факультету

Університету Короля Данила

\section{КРИМІНАЛІЗАЦІЯ КОРУПЦЙНИХ ПРАВОПОРУШЕНЬ У КК УКРАЇНИ ТА МІЖНАРОДНОМУ ПРАВІ: ПОРІВНЯЛЬНИЙ АНАЛІЗ}

Вибравши курс до економічного і політичного об'єднання європейських держав, Україна взяла на себе зобов'язання гармонізувати вітчизняні положення кримінальної антикорупиійної політики з нормами міжнародного права. Серед основних міжнародно-правових договорів у сфері запобігання корупиії, згоду на обов'язковість яких надано Верховною Радою України, виділяють Кримінальну конвениію Ради Європи про боротьбу з корупиією 1999 р. та Конвениію ООН проти корупиіі 2003 р. Однак, як показав порівняльно-правовий аналіз норм про криміналізащію корупщійних правопорушень иих Конвениій та КК України, питання імплементаиї̈ положень міжнародних антикорупиійних документів у законодавство України в аспекті кримінальної відповідальності за корупиійні правопорушення потребують пильної уваги законодавия.

Доведено, що поняття «службова особа» КК України $($ ст. ст. 18, 364) не узгоджується з Конвениію ООН проти корупиї (ст. 2) та Конвенцією про боротьбу з корупиією (ст. 1), які послуговуються термінологічним сполученням «посадова особа». Таке ж зауваження стосується і використання у КК України поняття «неправомірна вигода», оскільки Конвенції для позначення предмета корупиійних кримінальних правопорущень оперують поняттям «неправомірна перевага». Також встановлено неузгодженість ст. ст. 49, 80, 209, 3683, 3684, 369², 396 КК України із ст. ст. 18, 21, 23, 29 Конвениії ООН проти корупиії. Обгрунтовано, що прийняття ст. $368^{2}$ «Незаконне збагачення» КК, яка визнана неконституиійною і редакиія якої не відповідала ст. 20 Конвениії ООН проти корупиії уже на стадії ї розробки, було усвідомленим вольовим актом, який може мати власну корупиіиину історію з усіма правовими наслідками.

На підставі дослідження робиться висновок про те, що сучасний законотворчий процес містить недоліки не тільки щодо термінологічного та класифікачійного характеру у кримінально-правовому розумінні корупиійних правопорушень. Під час розробки та прийняття законів відбувається невиправдане використання складних конструкиій в описі способів вчинення таких порушень. Заборонні норми про корупиію не узгоджуються з іншими положенням КК та приписами міжнародного права.

Ключові слова: корупція, імплементація, міжнародні зобов'язання, корупційне кримінальне правопорушення, невідповідність норм.

Постановка проблеми. Протидія кримінальній корупційній протиправності, яка без сумніву, є одним із пріоритетних напрямів внутрішньої політики держави, значною мірою залежить від потенціалу органів, підрозділів та уповноважених осіб, що здійснюють таку діяльність. Тому високі вимоги, що висуваються до працівників антикоруп- ційних органів, поліцейських, мають бути підкріплені комплексом правових гарантій їньої діяльності, а також правовим забезпеченням, яке б дало можливість ефективно здійснювати покладені на них обов'язки.

Удосконалення законодавства 3 даної проблематики потребує підвищеної уваги i через те, що Україна є учасницею низки 
багатосторонніх міжнародних договорів, положення яких містять зобов'язання щодо криміналізації корупційних діянь, їх юрисдикції та правових наслідків вчинення таких діянь. Ключовими серед цих договорів є Кримінальна конвенція Ради Европи про боротьбу з корупцією 1999 року (далі Конвенція про боротьбу з корупцією) та Конвенція ООН проти корупції 2003 року.

Аналіз останніх досліджень і публікацій. Проблема криміналізації корупційних правопорушень є багатогранною

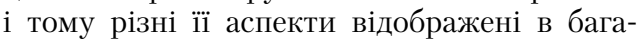
тьох наукових працях про кримінальну відповідальність за такі порушення. Зокрема, ці питання досліджували П. П. Андрушко, О. О. Дудоров, О. О. Житний, К. П. Задоя, В. М. Киричко, М. І. Мельник, В. О. Навроцький, В. Я. Настюк, Є. В. Невмержицький, В. І. Осадчий, А. В. Савченко, В. І. Тютюгін, М. І. Хавронюк, Н. М. Ярмиш, О. Д. Ярошенко та ін. Разом із тим питання імплементації положень міжнародних антикорупційних конвенцій у законодавство України в аспекті кримінальної відповідальності за корупційні правопорушення залишаються не досить розробленими.

Постановка завдання. В Україні на рівні правового регулювання протидії та запобігання корупції і пов'язаним із нею негативним явищам зроблено немало, зокрема: прийнято Закон України «Про запобігання корупції»; в КК України та КУпАП України внесено відповідні зміни; у низку інших нормативноправових актів запроваджено норми, які спрямовані на запобігання та протидію корупції, на нейтралізацію правопорушень, пов'язаних 3 корупцією. Однак правове регулювання антикорупційної діяльності не можна вважати досконалим, це стосується і законодавства про кримінальну відповідальність.

Мета статті полягає у тому, щоб дослідити питання кримінального переслідування за корупцію згідно з Конвенцією про боротьбу з корупцією та Конвенцією ООН проти корупції і визначити, наскільки повно та якісно її положення щодо криміналізації корупційних правопорушень імплементовані в КК України.

Виклад основного матеріалу. 3 аналізу змісту вже перших статей Конвенцій випливає, що у КК України у формулюванні антикорупційних норм не дотримано принаймні один із принципів правотворчості. Сутність його полягає в тому, що на етапі правотворення, встановлюючи, змінюючи чи скасовуючи правові норми, законодавчий орган повинен застосовувати однозначні терміни та єдину термінологію.
Зауваження насамперед стосується використання у КК України термінологічного словосполучення «службова особа». Так, у ст. 18 КК розкривається зміст цього поняття. Примітка до ст. 364 КК деталізує, які ж саме особи визнаються службовими у статтях $364,368,368^{5}, 369$ цього Кодексу [1]. Однак цими ж нормами службовими особами також визнано посадових осіб іноземних держав. Крім того, в інших вітчизняних нормативно-правових актах законодавець використав той же термін «посадова особа». Наприклад, у ст. 19 Конституції України зазначено: «..органи державної влади та органи місцевого самоврядування, ї посадові особи зобов'язані діяти...». Хоча в самому Основному Законі, далі, у ст. ст. 40, 56 , поряд із посадовими згадуються і службові особи. Відповідно до ст. 14 КУпАП посадові особи підлягають адміністративній відповідальності. Посадовою особою в контексті Закону України «Про державну службу» від 10.12.2015 вважається керівник державної служби в державному органі (ст. 2). I, як зазначено у ст. 2 Закону України «Про службу в органах місцевого самоврядування» від 07.06.2001, посадовою особою місцевого самоврядування є особа, яка працюе в органах місцевого самоврядування, має відповідні повноваження.

Поняття «службова особа» КК не узгоджується і з Конвенцію ООН проти корупції (ст. 2) [2] та Конвенцією про боротьбу з корупцією (ст. 1) [3], які послуговуються термінологічним сполученням «посадова особа».

3 огляду на зазначене, поняття спеціального суб'єкта кримінального правопорушення, в тому числі і корупційного, потребує уніфікації та приведення у відповідність як до національного, так і до міжнародного права.

Така ж заувага стосується і використання у КК України термінологічного словосполучення «неправомірна вигода», оскільки Конвенція ООН проти корупції (ст. ст. 15, 16, 18) [2] та Конвенція про боротьбу з корупцією (ст. 2, 3, 7, 8, 12) [3] для позначення предмета корупційних кримінальних правопорушень оперує поняттям «неправомірна перевага».

Необхідно також вказати на неузгодженість ст. $369^{2}$ КК України зі ст. 18 Конвенції ООН проти корупції щодо способу зловживання впливом. Цією Конвенцією передбачено, що дії у вигляді обіцянки, пропозиції або наданні державній посадовій особі чи будь-якій іншій особі будь-якої неправомірної переваги можуть вчинятися особисто або через посередників [2]. Вітчизняна норма, яка встановлює відповідальність за зловживання впливом, не передбачає такої деталізації. 
На перший погляд ця відмінність може здатися не настільки важливою, щоб на неї звертати увагу. Однак, поряд із вказівкою на посередництво, у міжнародно-правовому акті робиться акцент на тому, що такі особи теж повинні відповідати за корупцію. Звичайно, за українським законом про кримінальну відповідальність посередництво належить до інституту співучасті і винні особи несуть відповідальність за тією ж статтею, що й виконавець, з урахування ролі співучасника. Але саме під час призначення покарання таким посередникам виникне проблема щодо можливості застосування судом до них обмежень, передбачених законом для осіб, які безпосередньо вчинили корупційні правопорушення. Тобто, внаслідок приведення у відповідність вказаної норми КК до міжнародного стандарту, відбудеться не тільки формальна уніфікація законодавства. Це дасть можливість створити реальний механізм застосування до осіб, причетних до корупції, більш суворих заходів.

Аналогічний підхід Конвенцією $\mathrm{OOH}$ проти корупції застосовано і до побудови ст. 21 «Підкуп у приватному секторі». У цій нормі теж передбачено, що дії у формі обіцянки, пропозиції або надання будь-якої неправомірної переваги можуть вчинятися особисто або через посередників [2] Відповідні статті КК України, зокрема ст. $368^{3}$ «Підкуп службової особи юридичної особи приватного права незалежно від організаційно-правової форми» та ст. $368^{4} \ll П і д-$ куп особи, яка надає публічні послуги», не конкретизують поведінку суб'єкта злочину.

Далі, хоча колізія між нормами про незаконне збагачення Конвенції ООН проти корупції та КК України натепер вітчизняним законодавцем усунута, дослідження її попередньої редакції, яка визнана Конституційним Судом України такою, що не відповідає Конституції України, має важливе значення не тільки для майбутньої законотворчої діяльності. З'ясування причин такого, щонайменше недолугого, конструювання кримінального корупційного правопорушення необхідне для того, щоб встановити, чи була допущена фатальна помилка законотворців у ході криміналізації незаконного збагачення, чи це було свідоме рішення, яке може мати власну корупційну історію з усіма правовими наслідками.

Нагадаємо редакцію ст. $368^{2}$ «Незаконне збагачення» КК: «Набуття особою, уповноваженою на виконання функцій держави або місцевого самоврядування, у власність активів у значному розмірі, законність підстав набуття яких не підтверджено доказами...» [1]. Не вдаючись до детального аналізу зако- нодавчої конструкції цієї норми, оскільки це здійснив Конституційний Суд України у своєму рішенні № 1-р/2019 від 26.02.2019, наведемо лише підстави, які лягли в основу його прийняття. Отже, орган конституційної юрисдикції наголошує, що за приписами статей 62, 63 Конституції України законодавчим формулюванням складу такого злочину, як незаконнезбагачення, не можна:покладати на особу обов'язок підтверджувати доказами законність підстав набуття нею у власність активів, тобто доводити свою невинуватість; надавати стороні обвинувачення право вимагати від особи підтвердження доказами законності підстав набуття нею у власність активів; уможливлювати притягнення особи до кримінальної відповідальності лише на підставі відсутності підтвердження доказами законності підстав набуття нею у власність активів. У доктрині теж висловлюється подібна позиція [4, с. 197]

Особливо важливим тут є те, що на підставі цього рішення було в повному обсязі закрито 27 кримінальних проваджень, і 38 в частині ст. $368^{2}$ КК. Відповідальності уникнули народні депутати, посадовці центральних органів влади, судді, прокурори, працівники СБУ, поліції, Міноборони. Загальна сума статків, законність походження яких досліджували детективи НАБУ в цих провадженнях, становила близько 500 млн грн. [5].

Виникає логічне запитання: може, вітчизняного законодавця вчинити саме так наштовхнули взяті на себе міжнародні зобов'язання? Відповідь знаходимо у положеннях ст. 20 Конвенції ООН проти корупції, у якій прямо вказано: за умови дотримання своєї конституції та основоположних принципів своєї правової системи кожна держава-учасниця розглядає можливість вжиття таких законодавчих та інших заходів, які можуть бути необхідними для визнання злочином умисне незаконне збагачення, тобто значне збільшення активів державної посадової особи, яке перевищує ії̈ законні доходи і які вона не може раціонально обгрунтувати [2]. Покладення на особу обов'язку підтверджувати доказами законність підстав набуття нею у власність активів жодним чином не обумовлено. Цього немає уже і в новій редакції ст. $368^{5}$ про незаконне збагачення.

Цікавим тут є і той факт, що ще в Антикорупційній стратегії на 2014-2017 роки від 14.10.2014 серед інших заходів було передбачено приведення ст. $368^{2}$ КК у відповідність до ст. 20 Конвенції ООН проти корупції.

Не взяли до уваги на той час «борці 3 корупцією» і зауваження Головного юридичного управління Апарату Верховної Ради 
України до проекту Закону України «Про внесення змін до деяких законодавчих актів України щодо забезпечення діяльності Національного антикорупційного бюро України та Національного агентства з питань запобігання корупції» (реєстраційний № 1660-д). Цей підрозділ вже тоді попереджав народних депутатів, що за пропонованою ними редакцією ст. $368^{2}$ КК особа, уповноважена на виконання функцій держави або місцевого самоврядування чи близькі особи повинні будуть доказувати факт набуття активів у «значному розмірі» задля того, щоб їх не звинуватили у вчиненні такого злочину, як незаконне збагачення. Такий законодавчий підхід не враховує приписи статті 62 Конституції України щодо гарантії презумпції невинуватості.

Таким чином, гіпотетично створення саме такої конструкції (в редакції ст. $368^{2}$ ) було усвідомленим вольовим актом. Більше того, той факт, що до цієї статті було внесено ще п'ять змін після набрання нею чинності, свідчить про пильну увагу законодавця до норми. Однак законодавче визначення ознак незаконного збагачення так і не було приведене у відповідність до принципу юридичної визначеності. За такої ситуації залишається лише сподіватися на встановлення істини правоохоронними органами.

Деякі рекомендації Конвенції ООН проти корупції вітчизняному законодавцю слід урахувати і щодо відмивання доходів, здобутих злочинним шляхом. Зокрема, у цьому Міжнародному документі протиправними визнаються дії, які полягають у конверсії або переведені майна з метою приховання або маскування незаконного його походження [2]. Диспозицією ст. 209 «Легалізація (відмивання) доходів, одержаних злочинним шляхом» КК серед багатьох інших дій вказується, що приховування незаконного походження майна може відбуватися шляхом зміни його форми (перетворення). Як видно, вітчизняний закон не встановлює заборони вчиняти дії у формі конверсії. Хоча терміни «конверсія» та «переведення» не $\epsilon$ тотожними, а їх зміст - ідентичним. Тому, враховуючи наведене та те, що позначення альтернативних протиправних дій «конверсія» та «переведення» у міжнародному праві є системним (п. 1 ст. 1, п. 1 ст. 3 Конвенції ООН про боротьбу проти незаконного обігу наркотичних засобів і психотропних речовин), у ст. 209 КК необхідно внести відповідні зміни.

Також як дискусійну вносимо пропозицію про доцільність закріплення в окремій частині ст. 209 КК, як передбачено п. а ч. 1 ст. 23 Конвенції ООН проти корупції, відповідальності особи, яка з метою надання допомоги будь-якій особі, що бере участь у вчиненні основного злочину, щоб вона могла ухилитися від відповідальності за свої діяння, здійснює конверсію або переведення майна, здобутого злочинним шляхом.

I ще одне щодо легалізації (відмивання) доходів, одержаних злочинним шляхом. Національний закон це правопорушення не визнає корупційним. Тоді як і Конвенція ООН проти корупції і Конвенція про боротьбу з корупцією є однозначно ствердними щодо корупційної спрямованості цього посягання. Крім того, на те, що легалізація (відмивання) доходів, одержаних злочинним шляхом, $є$ злочином, пов'язаним з корупцією, звертають увагу авторитетні вчені [4, с. 205 6, с. 27]. 3 огляду на зазначене, вказану прогалину теж потрібно усунути, розширивши у ст. 45 КК перелік корупційних кримінальних правопорушень статтею 209 КК.

Також у контексті відповідності міжнародному праву потребує уваги законодавця і ст. 396 КК. Це випливає зі ст. 23 Конвенції $\mathrm{OOH}$ проти корупції, яка розглядає можливість вжиття державою-учасницею законодавчих та інших заходів для визнання приховання або безперервного утримання майна особою, якій відомо, що таке майно здобуте в результаті будь-якого зі злочинів, що визначений цією Конвенцією [2]. Слід вказати, що йдеться не стільки про формалізацію законодавчих приписів, скільки про створення правової підстави для застосування до осіб, які сприяли корупції, більш суворих обмежень та каральних заходів (мається на увазі звільнення від кримінальної відповідальності та від покарання, умовно-дострокове звільнення від відбування покарання і т. ін.).

I на завершення дослідження - щодо строків давності. Згідно зі ст. 29 Конвенції ООН проти корупції, кожна держава-учасниця встановлює тривалий строк давності для порушення провадження щодо будь-яких злочинів, що визначені цією Конвенцією, і встановлюе більш тривалий строк давності або можливість призупинення плину строку давності в тих випадках, коли особа, підозрювана у вчиненні злочину, ухиляється від правосуддя [2] Національне законодавство (ст. ст. 49, 80 КК) не передбачає збільшених строків давності для корупціонерів, що вказує на очевидну його невідповідність міжнародному закону і, без сумніву, підлягає виправленню.

\section{Висновки}

Підсумовуючи викладене, слід зазначити, що наведені прогалини у фактичній імплементації міжнародних кримінально-правових заборон - це лише невелика частка проблем, з якими доводиться стикатися суб'єктам правозастосовної практики. Недоліків у статтях КК про корупційні правопорушення набагато 
більше. Зокрема, самостійного дослідження потребує питання віднесення до категорії корупційних правопорушень тих, що передбачені ст. 160, ч. 3 ст. 206-2, ст. 365 , ст. 386 КК, та інших; поняття публічного підкупу, службового становища як ознаки підкупу службової особи; проблема застосування підстави звільнення за позитивної посткримінальної поведінки, передбаченої у ч. 5 ст. 354 КК; формулювання істотної шкоди як суспільно небезпечного наслідку окремих порушень даної категорії і навіть питання відповідності перекладу міжнародно-правових актів. Завдання ж цієї праці полягало в тому, щоб привернути увагу законодавця, вчених, практиків до витоків проблем, пов'язаних з реалізацію кримінально-правових норм.

Отже, проведена оцінка відповідності антикорупційних кримінально-правових приписів вітчизняного закону положенням Конвенції ООН проти корупції та Конвенції про боротьбу з корупцією показала, що в українського парламенту немає особливих прагнень до встановлення й заохочення ефективних світових практик, спрямованих на запобігання та припинення корупції. Процес імплементації міжнародних рекомендацій на стадії нормотворчості набув недбалого і безсистемного характеру, не враховує цілісності інституційної розбудови, відбувається з ігноруванням наукової думки та висновків спеціалістів. На стадії ж реалізації, в тому числі і застосування права викликає труднощі в тлумаченні змісту його нормативних приписів, що нерідко призводить до нівелювання усієї роботи антикорупційних органів, свідомої громадськості. Тому якщо держава в особі уповноважених органів в екс- треному порядку не проведе оцінку правових інструментів для визначення їхньої адекватності з точки зору протидії корупції, то наявна законодавча основа для формування та реалізації кримінальної антикорупційної політики неминуче зазнає краху.

\section{Список використаних джерел:}

1. Кримінальний кодекс України : Закон України від 5 квітня 2001 р. № 2341-III / Верховна Рада України. URL: https://zakon.rada.gov.ua/ laws/show/2341-14 (дата звернення: 18.03.2020).

2. Конвенція Організації Об'єднаних Націй проти корупції : прийнята на засіданні 58-ї сесії Генеральної Асамблеї ООН 31 жовтня 2003 р. // База даних «Законодавство Украӥни». URL: https://zakon.rada.gov.ua/laws/show/995 c16 (дата звернення: 17.03.2020).

3. Кримінальна конвенція Ради Європи про боротьбу з корупцією прийнята 27.01.1999 // База даних «Законодавство Украйни». URL: https://zakon.rada.gov.ua/laws/show / 994101 (дата звернення: 17.03.2020).

4. Корупційні схеми: їх кримінально-правова кваліфікація і досудове розслідування / за ред. М.І. Хавронюка. Київ : Москаленко О. М., 2019. $464 \mathrm{c}$

5. Повідомлення Національного антикорупційного бюро України «Після рішення Конституційного суду усі справи щодо незаконного збагачення закрито». НАБУ: веб-сайт. URL: https://nabu.gov.ua/novyny/pislya-rishennyakonstytuciynogo-sudu-usi-spravy-shchodonezakonnogo-zbagachennya-zakryto (дата звернення: 21.03.2020)

6. Савченко А.В. Корупційні злочини (кримінально-правова характеристика) : навчальний посібник. Київ: «Центр учбової літератури», 2016. 168 с.

Choosing the course for economic and political unification with European states, Ukraine has undertaken the obligation to harmonize domestic principals of criminal anti-corruption policy with the norms of international law. Among the most important international legal treaties in the field of corruption prevention, the consent of which was granted by the Verkhovna Rada of Ukraine, the Council of Europe Criminal Convention on Corruption of 1999 and the UN Convention against Corruption in 2003 can be exuded. However, as the comparative legal analysis of the norms on the criminalization of corruption offenses of these Conventions and the Criminal Code of Ukraine showed, the issue of implementation of the provisions of international anti-corruption documents in the legislation of Ukraine, in the aspect of criminal liability for corruption offenses, needs close attention of the legislator.

It is proved that the concept of "official" of the Criminal Code of Ukraine (Articles 18,364) is not consistent with the UN Convention against Corruption (Article 2) and the Convention on Combating Corruption (Article 1), which use the term "official" ". It is also defined the inconsistency of articles 49, 80,209,3683,3684,3692,396 of the Criminal Code of Ukraine with articles 18,21, 23, 29 of the UN Convention against Corruption. It is substantiated that the adoption of art. $368^{2}$ the "Illegal enrichment" of the Criminal Code, which was declared unconstitutional and the edition of which did not comply with art. 20 of the UN Convention against Corruption at the stage of its elaboration, was a deliberate act of will, which may have its corrupt history with all legal consequences.

Based on the research, a conclusion can be made that the current lawmaking process contains shortcomings not only in terms of terminology and classification in the criminal law sense of corruption offenses. During the elaboration and adoption of laws, the unjustified use of complex structures in describing ways of committing such violations takes place. The restrictive norms on corruption are not consistent with other provisions of the Criminal Code and the provisions of international law.

Key words: corruption, corrupt criminal offense, implementation, international obligations, unity of terminology. 